\title{
Dose in continuous renal replacement therapy
}

\author{
Rolando Claure-Del Granado
}

Hospital Obrero \#2 - C.N.S., Universidad Mayor de San Simon, School of Medicine, Cochabamba, Bolivia

\begin{abstract}
Continuous renal replacement therapy (CRRT) is one of the most used types of renal replacement therapies for the treatment of critically ill patients with acute kidney injury (AKI). Recent practice clinical guidelines based on recent clinical trials recommend a prescribed dose of $20-25 \mathrm{~mL} / \mathrm{kg} / \mathrm{h}$ of effluent since these trials could not find differences between high-intensity versus low-intensity CRRT dose and different outcomes as mortality and recovery of renal function. Nevertheless, the results of these recent trials do not mean that CRRT dose is not important, and on the contrary, these trials inform us that dose needs to be continuously assessed and modified according to clinical, metabolic, and physiological needs of each patient. Dose prescription in CRRT needs to be a dynamic and precise process, in which evidence-based quality measures will be used to guide CRRT dose prescription that will match daily patients needs. Delivered dose should be routinely monitored to ensure that it will be achieved. Quality measures for monitoring delivered dose of CRRT have been proposed, but they still need validation, before be implemented into clinical practice.
\end{abstract}

KEY WORDS: Continuous renal replacement therapy. Acute kidney injury. Prescribed dose. Delivered dose. Urea.

\section{Resumen}

Las terapias de reemplazo renal continuo (TRRC) son de los tipos mas empleados de terapias de reemplazo renal para el tratamiento de pacientes con lesión renal aguda (IRA) críticamente enfermos. Guías de practica clínica recientemente publicadas basadas en estudios clínicos recomiendas prescribir una dosis de efluente de 20-25 m/ $/ \mathrm{kg} / \mathrm{h}$, ya que estos ensayos clínicos no pudieron encontrar diferencias en desenlaces como mortalidad o recuperación de la función renal. Sin embargo, el resultado de estos ensayos clínicos recientes no significan que la dosis en TRRC no sea importante, por el contrario estos estudios nos muestran que la dosis tienen que ser continuamente evaluada y modificada de acuerdo a las necesidades clínicas, metabólicas, y fisiológicas de cada paciente. La prescripción de dosis en TRRC necesita ser un proceso dinámico y preciso, en el cual medidas de calidad basadas en evidencia serian empleadas para guiar la prescripción de dosis que cubra las necesidades diarias del paciente. La dosis proporcionada debe de ser constantemente monitorizada para asegurar de que esta sea lograda. Se han propuesto medidas de calidad para la monitorización de la dosis entregada de TRRC, pero aun necesitan ser validadas antes de ser implementadas en la practica clínica diaria.

PALABRAS CLAVES: Terapia de reemplazo renal continuo. Lesión renal aguda. Dosis prescrita. Dosis administrada.

\author{
Correspondence: \\ Rolando Claure-Del Granado \\ Hospital Obrero \#2 - C.N.S. \\ Universidad Mayor de San Simon, School of Medicine Date of reception: 22-11-2017 \\ Cochabamba, Bolivia \\ Date of acceptance: 08-03-2018 \\ E-mail: rclaure@yahoo.com
}

Gac Med Mex. 2018;Supp 1:40-47

Contents available at PubMed www.anmm.org.mx 


\section{Introduction}

Continuous renal replacement therapy (CRRT) dose delivery has traditionally been based on urea clearance as a surrogate marker of low molecular weight uremic toxins ${ }^{1}$. In CRRT, since small solute clearance is approximately equal to the effluent flow, dose is usually prescribed in terms of effluent per kilogram of body weight per unit of time $(\mathrm{mL} / \mathrm{kg} / \mathrm{h})$ as this dose expression has been related to the technical process of solute removal ${ }^{2}$. In the last years, new evidence has emerged to address the issue of optimal CRRT dose and methods for monitoring it ${ }^{3}$. Two recent multicenter high-quality randomized controlled trials focused on defining the association of delivered dose of dialysis and outcomes in critically ill patients have been published ${ }^{4,5}$; their findings have helped to modify key content in recent clinical practice guidelines for dose prescription and delivery of CRRT in the management of critically ill patients with acute kidney injury $(\mathrm{AKI})^{3}$.

Three initial studies that assessed the relationship between dialysis dose and outcomes showed an association between a higher dialysis dose and better outcomes ${ }^{1,6,7}$; however, most recent trials did not confirm this benefit ${ }^{4,5,8-10}$ nor improve kidney recovery among critically ill patients with AKI. However, these trials do not mean that dose is not important, but that it needs to be continuously assessed and modified according to clinical, metabolic, and physiological needs of each patient. Dose prescription in CRRT needs to be a dynamic and precise process, in which evidence-based quality measures will be used to guide CRRT dose prescription ${ }^{11}$.

\section{The concept of dose in renal replacement therapy (RRT)}

The dose of any drug is designed to elicit a measurable response by specific variables that represent the underlying condition being treated. For instance, antihypertensive doses are targeted to achieve a specific change in blood pressure. Consequently, dose definitions need to encompass not only the elements that are quantitatively modified but also what response variable they are targeting. Since all forms of dialysis can remove or add solutes and fluids, a dose in RRT could then be defined as a measure of the quantity of a representative marker that is removed or added to a patient. Therefore, dose definition has to be quantitative and associated with a measurable change in the desired outcomes of solute and fluid homeostasis ${ }^{12}$.

In CRRT, the dose is most commonly defined by extracorporeal urea clearance ${ }^{1}$. Since urea has a sieving coefficient close to 1 , its clearance is reasonably estimated by weight-based effluent flow rate and it is expressed as $\mathrm{mL} / \mathrm{kg} / \mathrm{h}^{13}$. Urea is a commonly used marker as it is readily available and is inexpensive, even though evidence from chronic kidney disease has suggested that urea per se is not a major azotemic toxin and is unlikely to play a major pathogenic role in patients with $A \mathrm{KI}^{14}$. Another important point is that any dose expression only becomes relevant if it can be related to patient outcomes ${ }^{15}$. Clearance of urea and middle molecular weight molecules may not be the major determinants of short-term outcomes (days to weeks) in patients with $\mathrm{AKI}^{16}$. As suggested by Davenport and Farrington, the adequate removal of what they call "very small waste products" (potassium, sodium, and hydrogen ions) and fluid overload are the main determinants of RRT adequacy in patients with AKI since the consequences of their accumulation could be lethal in hours to days ${ }^{16}$. Evidence about the important relationship of fluid overload as an independent predictor of increased mortality similarly suggests that other variables need to be considered in dose of RRT ${ }^{17-22}$. Unfortunately, these parameters (e.g., potassium, acid-base balance, and fluid overload) have never been included in randomized dose studies as a dialysis adequacy measurement. The concept of dose needs to be reevaluated and markers in several domains should be included in the definition and in the measurement of dialysis dose ${ }^{12}$.

\section{Dose - outcomes studies}

Since dialysis dose was associated to clinical outcomes in patients with end-stage renal disease as showed in an early study of Lowrie et $a .^{23}$ and with the subsequent observational studies that showed that survival was improved at higher doses of dialysis, the concept of providing higher dialysis doses to improve patients outcomes has been applied to $\mathrm{AKI}^{24-26}$.

Three initial randomized controlled trials showed the same association between a higher dialysis dose and better outcomes ${ }^{1,6,7}$; however, most recent trials did not confirm this benefit ${ }^{4,5,8-10}$. In the United States, the VA/ $\mathrm{NIH}$ Acute Renal Failure Trial Network (ATN) study, 1124 critically ill patients with AKI were treated with intermittent hemodialysis (IHD), CRRT, or prolonged intermittent 
RRT (PIRRT) based on hemodynamic status ${ }^{4}$. Patients were randomly assigned to one of two dosing arms: Intensive therapy, where IHD and PIRRT were given 6 times per week with a target Kt/V of 1.2-1.4 per treatment (median delivered dose of 1.3 per treatment), while CRRT was provided with an effluent flow rate of $35 \mathrm{~mL} /$ $\mathrm{kg} / \mathrm{h}$; or less intensive therapy, where IHD and PIRRT were given 3 times per week with a target $\mathrm{Kt} / \mathrm{V}$ of 1.2-1.4 per treatment (median delivered dose of 1.3 per treatment), while CRRT was provided with a flow rate of $20 \mathrm{~mL} / \mathrm{kg} / \mathrm{h}$. The death rate at day 60 was the same for both groups (53.6\% with intensive therapy and $51.5 \%$ with less intensive therapy). In addition, the duration of RRT and the rate of recovery of kidney function or non-renal organ failure were similar for both treatment arms. The group that received intensive therapy had an increased number of hypotensive episodes. Therefore, this study showed that more intensive renal support beyond that obtained with a standard thrice weekly regimen (with a target Kt/V of 1.2 to 1.4 per treatment) or standard CRRT (with an effluent flow rate of $20 \mathrm{~mL} / \mathrm{kg} / \mathrm{h}$ ) does not improve clinical outcomes.

In Australia and New Zealand, the Randomized Evaluation of Normal versus Augmented Level of Replacement Therapy (RENAL) study, 1508 critically ill patients with AKI were randomly assigned to continuous venovenous hemodiafiltration (CVVHDF) at an effluent flow of either $25 \mathrm{~mL} / \mathrm{kg} / \mathrm{h}$ (lower-intensity group) or $40 \mathrm{~mL} / \mathrm{kg} / \mathrm{h}$ (higher-intensity group) $)^{5}$. At 90 days, mortality was the same between groups $(44.7 \%$, with an odds ratio of $1.00,95 \%$ confidence interval $[\mathrm{Cl}]$ 0.31-1.23). In addition, the proportion of patients who continued to receive RRT at 90 days was similar with both dialysis doses $(6.8 \%$ and $4.4 \%$ of high-intensity and low-intensity groups with an odds ratio of $1.59,95 \% \mathrm{Cl} 0.86-2.92$ ).

Based on the results of the recent trials mentioned above, the Kidney Disease Improving Global Outcomes (KDIGO) AKI Clinical Practice Guideline recommends delivery of an effluent dose of $20-25 \mathrm{~mL} / \mathrm{kg} / \mathrm{h}$ in $\mathrm{CRRT}^{3}$. Since then, two additional randomized controlled trials focused on the potential clinical benefits of high volume CRRT in critically ill septic patients with AKI have been published ${ }^{27,28}$. In the first study, a total of 140 critically ill patients with septic shock and AKI were randomized to either high volume hemofiltration (HVHF) at $70 \mathrm{~mL} / \mathrm{kg} / \mathrm{h}$ or standard-volume hemofiltration (SVHF) at $35 \mathrm{~mL} / \mathrm{kg} / \mathrm{h}$ for a 96 -h period. Mortality at 28 days was lower than expected but not different between groups (HVHF $37.9 \%$ vs. SVHF $40.8 \%, p=0.94)^{27}$. In the second study, Park et al. compared conventional $(40 \mathrm{~mL} / \mathrm{kg} / \mathrm{h})$ versus high
(80 mL/kg/h) prescribed doses of CVVHDF in septic patients with AKI. There were no differences in 28-day mortality (Hazard ratio [HR], 1.02; $95 \% \mathrm{Cl} 0.73-1.43$; $p=0.9$ ) or 28 -day kidney survival (HR, 0.96 ; $95 \%$ $\mathrm{Cl} 0.48-1.93 ; p=0.9$ ) between groups ${ }^{28}$.

Finally, a recent Cochrane systematic review that included six studies enrolling 3185 participants has shown that more intensive CRRT did not demonstrate beneficial effects on mortality or recovery of kidney function in critically ill patients with AKI. There was an increased risk of hypophosphatemia with more intense CRRT. However, intensive CRRT reduced the risk of mortality in patients with post-surgical $\mathrm{AKI}^{29}$.

\section{Prescribed versus delivered dose}

Among clinicians, there is an underappreciation of the difference between the dose that is prescribed and the dose that is actually delivered ${ }^{15}$. In recent randomized trials that have explored the relationships between CRRT dose and different outcomes, more than $80 \%$ of the prescribed dose was delivered $d^{1,4,5,7,8,10}$. Nevertheless, one must considered that to maintain a prescribed dose, those trials have employed some strategies that are not common in daily clinical practice. For instance, in Ronco et al. study, ${ }^{1}$ when prescribed dose felt short, effluent volume was increased on the next day to achieve a target dose, and filters were routinely changed every $24 \mathrm{~h}$ according to institutional practice.

Some observational studies which performed outside the relative controlled environment of a randomized trial could better exemplify what happens in daily clinical practice, where the prescribed delivered gap of CRRT dose was higher (Table 1). In an early study, Venkataraman et al. evaluated 115 patients treated with CRRT $^{30}$. The delivered dose of CRRT for each patient/day was calculated from the hourly effluent flow rate, the patient's weight, and the duration (in hours) of CRRT and was expressed as mean effluent flow rate (in $\mathrm{L} / \mathrm{h}$ ). The mean \pm standard deviation number of hours per day on CRRT was $16.1 \pm 3.53$, with a mean flow rate (averaged over $24 \mathrm{~h}$ ) of $1.36 \pm 0.31 \mathrm{~L} / \mathrm{h}$. The mean CRRT dose prescribed for these patients was $24.46 \pm 6.73 \mathrm{~mL} / \mathrm{kg} / \mathrm{h}$, but the mean dose delivered was only $16.55 \pm 5.41 \mathrm{~mL} / \mathrm{kg} / \mathrm{h}(68 \%$ of the prescribed dose, $p<0.001)$. Clotting of the extracorporeal circuit was the most common cause of downtime.

In the Do-RE-MI study, $80 \%$ of the patients that required RRT were placed on $\mathrm{CRRT}^{9}$. Dose was 
Table 1. Differences between prescribed and delivered dose in recent RRT dose studies

\begin{tabular}{|c|c|c|c|c|}
\hline Reference & Dialysis Modality & Prescribed & Delivered & $\%$ of Delivered Dose \\
\hline Evanson et al. 1998 & IHD & $\mathrm{Kt} / \mathrm{V} 1.25 \pm 0.47$ & $\mathrm{Kt} / \mathrm{N} 1.04 \pm 0.49$ & 83.5 \\
\hline Evanson et al. 1999 & IHD & $\mathrm{Kt} / \mathrm{V} 1.11 \pm 0.32$ & $\begin{array}{l}\text { spKt/N } 0.9 \pm 60.33 \\
\text { eKt/N } 0.8 \pm 40.28 \\
\text { dpKt/N } 0.84 \pm 0.30\end{array}$ & $86.4-75.5$ \\
\hline Venkataraman et al. 2002 & CRRT & $24.5 \pm 6.7 \mathrm{~mL} / \mathrm{Kg} / \mathrm{h}$ & $16.6 \pm 5.4 \mathrm{~mL} / \mathrm{Kg} / \mathrm{h}$ & 68 \\
\hline Tolwani et al. 2008 & CRRT & $\begin{array}{l}\text { Standard } 20 \mathrm{~mL} / \mathrm{Kg} / \mathrm{h} \\
\text { High } 35 \mathrm{~mL} / \mathrm{Kg} / \mathrm{h}\end{array}$ & $\begin{array}{l}17 \mathrm{~mL} / \mathrm{Kg} / \mathrm{h} \\
29 \mathrm{~mL} / \mathrm{Kg} / \mathrm{h}\end{array}$ & $\begin{array}{l}85 \\
82\end{array}$ \\
\hline Vesconi 2009 et al. & CRRT & $34.3 \mathrm{~mL} / \mathrm{Kg} / \mathrm{h}$ & $27.1 \mathrm{~mL} / \mathrm{Kg} / \mathrm{h}$ & 79 \\
\hline Claure-Del Granado et al. 2011 & CRRT & $30.2 \mathrm{~mL} / \mathrm{Kg} / \mathrm{h}$ & $22.3 \mathrm{~mL} / \mathrm{Kg} / \mathrm{h}$ & 73 \\
\hline
\end{tabular}

categorized into more intensive (CRRT $\geq 35 \mathrm{~mL} / \mathrm{kg} / \mathrm{h}$ ) or less intensive (CRRT $<35 \mathrm{ml} / \mathrm{kg} / \mathrm{h})$. The main outcome measures were ICU mortality, ICU length of stay, and duration of mechanical ventilation. The median delivered dose was $27.1 \mathrm{~mL} / \mathrm{kg} / \mathrm{h}$ (interquartile range $=22.1-33.9$ ), with only $22 \%$ of patients receiving the prescribed dose in the more intensive group, with circuit clotting being the main cause in $74 \%$ of cases.

Finally, Claure-Del Granado et al. performed a comprehensive analysis of prescribed versus delivered dose of dialysis in 52 critically ill patients with AKI treated with pre-dilution $\mathrm{CVVHDF}^{31}$. Despite the use of citrate anticoagulation, filter clotting was the single leading cause of therapy downtime, while other causes not related to filter or extracorporeal circuit were collectively more common. Delivered dose (based on urea clearance) estimated from standard CRRT clearance equations that accounted for pre-dilution was only $73 \%$ of the prescribed dose. Therefore, treatment downtime and pre-dilution combined to produce on average a $27 \%$ decline in the urea clearance actually delivered.

\section{Factors affecting the delivery of the prescribed dose}

There are two types of factors that play a role while delivering a prescribed dialysis dose: those related to the patient and those related to the therapy itself.

\section{Patient-related barriers}

Patient-related barriers that influence the delivery of a prescribed dose in RRT are urea generation rate and the volume of distribution of uremic solutes ${ }^{15}$. Hypercatabolic state of critical patients with AKI alters urea generation rate, and this makes this parameter unpredictable ${ }^{32}$. AKI patients also have an expanded and variable urea volume of distribution which contributes to increase the gap between prescribed and delivered dose, and it is perhaps the single most important issue in delivering a prescribed dose ${ }^{32}$. A volume overload state may lead to an overestimation of the delivered dose possibly by enhancing urea rebound, especially, when dialysis is rapidly delivered (in the case of IHD) where the average post-dialysis urea rebound could be $11.4 \%^{33}$. In hybrid therapies, a lower post-dialysis urea rebound $(4.1 \%)$ is expected due to the slower rate of solute removal ${ }^{34}$. During CRRT, post-dialysis urea rebound is not an issue because of the slower rate of solute removal and its continuous nature ${ }^{34}$. Another important factor that has to be taken into account is that urea volume of distribution does not correlate with its anatomical equivalent which is body weight as has been previously shown, and estimates of total water body cannot be used as a surrogate for urea volume of distribution in determining dialysis adequacy ${ }^{35}$.

\section{Treatment-related barriers}

There are two important treatment-related factors that influence the delivery of a prescribed dose; the first one is the function of the catheter and the second one is the function of the filter.

Dialysis catheters are essential for immediate vascular access and are widely used in critically ill patients with AKI. Catheter dysfunction, leading to premature dialysis interruptions due to catheter change or catheter reversal, decreases treatment time and consequently decreases delivered dialysis dose ${ }^{36}$. Catheter dysfunction is commonly manifested by reduced blood flow and increased access recirculation as 


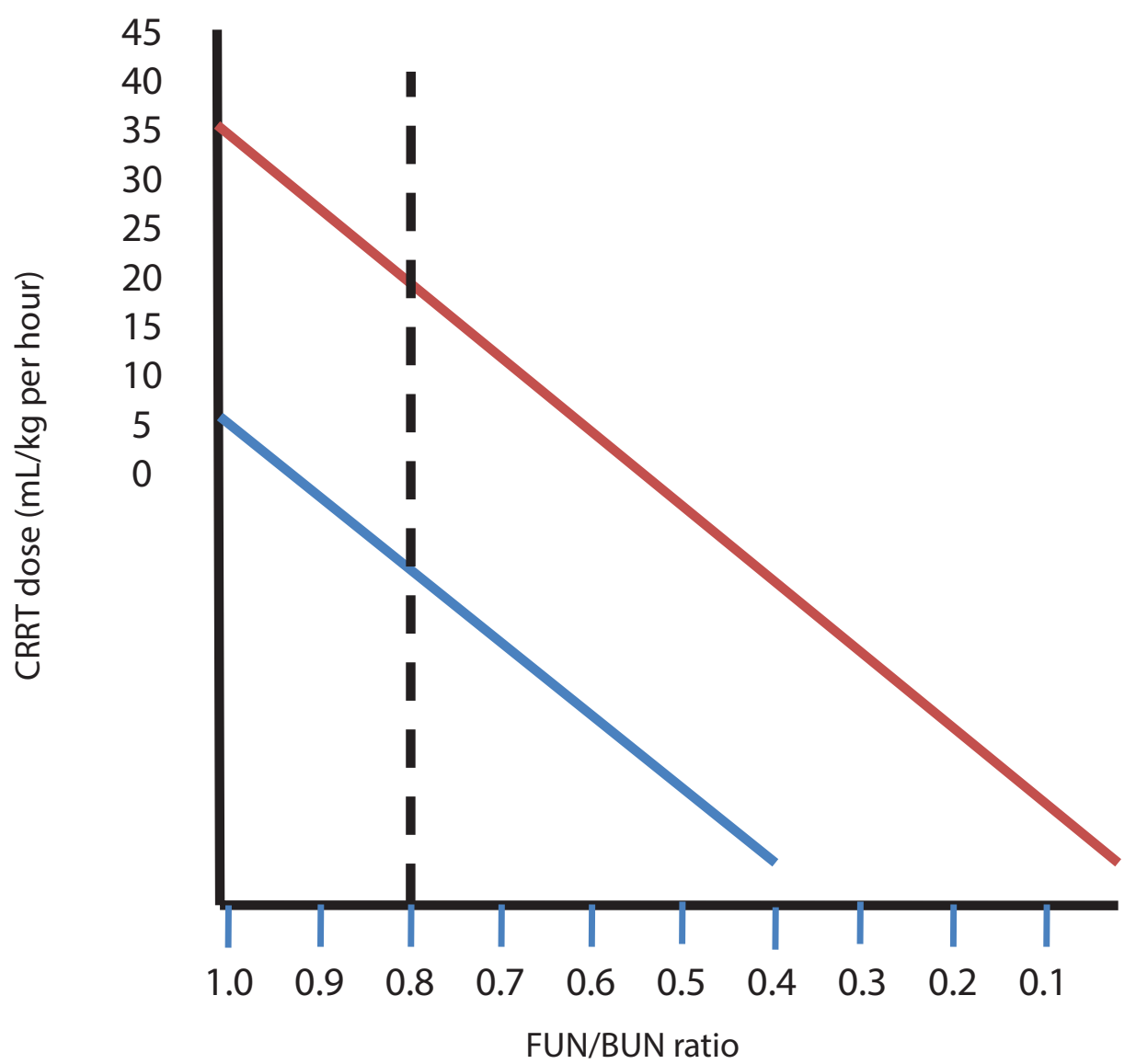

Figure 1. Decline in delivered CRRT dose as a result of reducing filter efficacy. When FUN/BUN ratio reaches 0.8 , the prescribed dose ranges between 25 and $20 \mathrm{~mL} / \mathrm{kg} / \mathrm{h}$ (light blue box) recommended by KDIGO Clinical Practice Guidelines for AKI falls below $20 \mathrm{~mL} / \mathrm{kg} / \mathrm{h}$. Blue line shows standard intensity CRRT dose prescription, and the red line shows high-intensity CRRT dose prescription (e.g., ATN and RENAL trials) CRRT: continuous renal replacement therapy, FUN: effluent urea nitrogen, BUN: blood urea nitrogen, KDIGO: Kidney Disease Improving Global Outcomes, AKI: acute kidney injury.

shown in several studies ${ }^{37-40}$. In a recent study, the site and the type of catheter were the two main factors involved in catheter performance ${ }^{41}$. The use of polyurethane non-tunneled catheters (PNT-Caths) was compared to silicone-tunneled catheters (ST-Caths) placed at the femoral site in 30 critically ill patients with AKI treated with IHD and/or CVVHDF. The authors found that the incidence of thrombosis and catheter-related infections was lower with ST-Caths. The number of interruptions, of reversals, and the ratio of venous return pressure to catheter blood flow were significantly lower with ST-Caths. No differences were found between ST-Caths and PNT-Caths in terms of recirculation and blood flow rates. Patients with ST-Caths have a higher delivered/prescribed dose ratio.

Filters play an important role in delivering dialysis dose; in fact, the major barrier to therapy delivery is the inability to keep the therapy going for the full-prescribed time due to filter clotting as previous discussed trials have shown $9,30,31,42$. Concentration polarization constitutes a factor that also contributes to the decline in filter permeability; this phenomenon is caused by layering of proteins forced into the membrane by ultrafiltration and results in the formation of a pseudomembrane increasing the thickness of the original membrane. The consequences are not only the need for a higher transmembrane pressure to maintain the ultrafiltration rate but also a lower concentration of potentially important solutes in the ultrafiltrate $^{43}$. Macedo et al. have previously showed the effect of filter function on delivered dose in ATN and RENAL trials ${ }^{44}$. Using effluent urea nitrogen/blood urea nitrogen (FUN/BUN) ratios from a previous trial ${ }^{31}$, Macedo et al. evaluated the real effect of loss of filter efficacy due to clotting or concentration polarization on delivered CRRT dose. In both ATN and RENAL trials, patients assigned to an intensive dose ( $35 \mathrm{~mL} / \mathrm{kg} / \mathrm{h}$ and $40 \mathrm{~mL} / \mathrm{kg} / \mathrm{h}$, respectively) and whose filter efficacy decline over time (FUN/BUN ratio < 0.8 ) 
Table 2. Proposed quality measures for CRRT dose

\begin{tabular}{llc}
\hline Metric & Calculation & Target \\
\hline Dose clearance & FUN/BUN ratio & $\geq 0.8$ \\
$\begin{array}{l}\text { Delivery/Prescribed dose } \\
\text { ratio }\end{array}$ & Average effective delivered/prescribed dose & $\geq 0.8$ \\
Effective time of treatment & 24 - downtime (hours) & $\geq 20$ \\
Solute control indicators & Solute $_{\text {Day }(x+1)} /$ solute $_{\text {Day }(x)}$ & $\leq 1.0$ \\
Circuit control indicators & Relative or absolute changes in pressure drop or in the transmembrane & To be \\
& pressure & defined \\
\hline CRRT: continuous renal replacement therapy, FUN: effluent urea nitrogen, BUN: blood urea nitrogen &
\end{tabular}

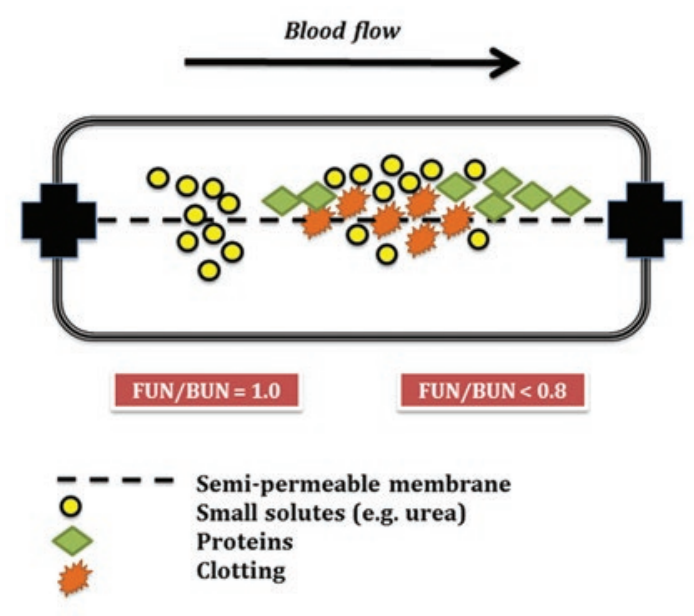

Figure 2. The effect of filter clotting and concentration polarization on CRRT dose.

Filter clotting and concentration polarization (protein deposition) occur over time on the membrane reducing the membrane surface available for convection and diffusion of solutes, decreasing the delivered dose of dialysis. Measuring FUN/BUN ratio could help to assess this phenomenon and should be continuously monitored during CRRT. FUN: effluent urea nitrogen, BUN: blood urea nitrogen, CRRT: continuous renal replacement therapy.

could have received a dose similar to the upper limit of the less intensive dose group $(20 \mathrm{~mL} / \mathrm{kg} / \mathrm{h}$ in ATN and $25 \mathrm{~mL} / \mathrm{kg} / \mathrm{h}$ in RENAL) ${ }^{44}$. As shown in figure 1 , urea clearance decreases as filter function declines.

Another important factor that contributes to deliver a prescribed dose and that is not usually taken into account while assessing dialysis dose is the interaction between convection and diffusion inside the membrane. This interaction affects the overall clearance for small solutes making it significantly lower than the sum of the dialytic clearance and the ultrafiltration flow rate (Fig. 2). This is explained by the reduction in the convective mass transport proportional to the reduction in the solute concentration due to diffusion. There is also an increase in blood transfer resistance secondary to the decrease in the blood flow that affects the diffusive mass transfer ${ }^{45}$. As shown in figure 2 , in treatments where fluid is removed, ultrafiltration of the plasma water results in increasing red blood cells and plasma protein concentrations along the blood path limiting total effluent and as a consequence reducing clearance of small solutes ${ }^{46}$.

\section{Precision CRRT dose delivery}

Effluent flow $(\mathrm{mL} / \mathrm{kg} / \mathrm{h})$ is an acceptable surrogate for prescription of CRRT dose for solute clearance in critically ill patients with AKI. Prescribed dose should be $20-25 \mathrm{~mL} / \mathrm{kg} / \mathrm{h}$ if urea is used as a surrogate marker of clearance of small molecular weight solutes; however, one must have in mind that the prescribed dose is a dynamic process and that the prescribed dose range can be modified depending on patient demand and in response to continuous evaluation of quality measures proposed by the acute dialysis quality initiative consensus group ${ }^{11}$. These quality measures are the measure of solute clearance, the delivery/prescribed dose ratio, the effective time of treatment, a solute control indicator, and circuit and pressure trends ${ }^{11}$. Table 2 shows the metrics and targets of each of these parameters.

For example, a hypercatabolic critically ill patient with AKI (e.g., rhabdomyolysis or tumor lysis syndrome) may initially required higher prescribed dose of CRRT (> $25 \mathrm{~mL} / \mathrm{kg} / \mathrm{h}$ ) to achieve acceptable solute control. Thereafter, as patient condition improves, the prescribed dose could be reduced to the range of $20-25 \mathrm{~mL} / \mathrm{kg} / \mathrm{h}$ and could be further decreased to $<20 \mathrm{ml} / \mathrm{kg} / \mathrm{h}$ as renal function improves.

Dose delivery should be regularly reassessed and modified based on continuous evaluation of quality measures mentioned above, and this must be done at least once every $24 \mathrm{~h}$. A higher dose than 20$25 \mathrm{~mL} / \mathrm{kg} / \mathrm{h}$ may be indicated if the target level of a specific solute (e.g., urea) cannot be achieved. The delivered dose in CRRT can also result in the 
clearance of unintended solutes, potentially contributing to adverse events and causing significant electrolyte derangements due to the removal of solutes (e.g., potassium and phosphorus) from the blood without adequate replacement ${ }^{47,48}$. These electrolyte derangements such as hypophosphatemia and hypokalemia have been associated with respiratory muscle weakness, delayed ventilator weaning, myocardial dysfunction, rhabdomyolysis, and cardiac dysrhythmias; all of them associated with increased mortality in critically ill patients with AKI. Delivered dose in CRRT has also the inadvertent consequence of increasing the clearance of drugs and can result in the potential suboptimal dosing of antibiotics; therefore, the influence of CRRT dose must be taken into account when prescribing antibiotics or other medications ${ }^{49,50}$. CRRT dose may also impact nutritional parameters since CRRT clears low molecular weight water-soluble substances, glucose, amino acids, low molecular weight proteins, vitamins, and trace elements; therefore, continuous monitoring of these parameters should also be part of the dynamic process of CRRT dose delivery ${ }^{51,52}$.

In summary, the assessment of delivered dose should be a continuous process since operational characteristics of CRRT and patient requirements change over time ${ }^{12}$. The evaluation of delivered dose should not be limited to the determination of small solute clearance (e.g., urea) but extended to essential components of dose in critically ill patients with AKI such as fluid balance, acid-base homeostasis, adequate adjustment of antibiotics dose, and monitoring nutritional parameters as was previously proposed ${ }^{12}$.

\section{Conclusions}

The results of the most recent dose randomized clinical trials studies suggested that further increases of dose above a threshold (prescription target of 20$25 \mathrm{~mL} / \mathrm{h}$ ) would not translate into better outcomes. They also showed that dose is still an important factor in the care of patients with AKI and that special attention has to be given to some operational characteristic of the treatment (e.g., filter function) affecting the delivery of a prescribed dose. CRRT dose prescription and delivery are a dynamic process, which requires specific quality measures for monitoring both processes; however, these quality measures need to be further validated. Providing more accurate parameters of delivered dose will improve precision dose delivery and assessment of the effect of dose on different outcomes in critically ill patients treated with CRRT.

\section{References}

1. Ronco $C$, Bellomo $R$, Homel $P$, et al. Effects of different doses in continuous veno-venous haemofiltration on outcomes of acute renal failure: a prospective randomised trial. Lancet. 2000;356:26-30.

2. Neri M, Villa G, Garzotto F, et al. Nomenclature for renal replacement therapy in acute kidney injury: basic principles. Crit Care. 2016;20:318.

3. Copyright and License Information. Section 5: dialysis Interventions for Treatment of AKI. Kidney Int Suppl (2011). 2012;2:89-115.

4. VA/NIH Acute Renal Failure Trial Network, Palevsky PM, Zhang JH, et al. Intensity of renal support in critically ill patients with acute kidney injury. N Engl J Med. 2008;359:7-20.

5. RENAL Replacement Therapy Study Investigators, Bellomo R, Cass A, et al. Intensity of continuous renal-replacement therapy in critically ill patients. N Engl J Med. 2009;361:1627-38.

6. Schiffl H, Lang SM, Fischer R. Daily hemodialysis and the outcome of acute renal failure. N Engl J Med. 2002:346:305-10.

7. Saudan $P$, Niederberger M, De Seigneux $S$, et al. Adding a dialysis dose to continuous hemofiltration increases survival in patients with acute renal failure. Kidney Int. 2006:70:1312-7.

8. Tolwani AJ, Campbell RC, Stofan BS, et al. Standard versus high-dose CVVHDF for ICU-related acute renal failure. J Am Soc Nephrol. 2008; 19:1233-8.

9. Vesconi S, Cruz DN, Fumagalli R, et al. Delivered dose of renal replacement therapy and mortality in critically ill patients with acute kidney injury. Crit Care. 2009;13:R57.

10. Bouman CS, Oudemans-Van Straaten HM, Tijssen JG, Zandstra DF, Kesecioglu J. Effects of early high-volume continuous venovenous hemofiltration on survival and recovery of renal function in intensive care patients with acute renal failure: a prospective, randomized trial. Crit Care Med. 2002;30:2205-11.

11. Bagshaw SM, Chakravarthi MR, Ricci Z, et al. Precision continuous renal replacement therapy and solute control. Blood Purif. 2016;42:238-47.

12. Claure-Del Granado R, Mehta RL. Assessing and delivering dialysis dose in acute kidney injury. Semin Dial. 2011;24:157-63.

13. Ricci Z, Salvatori G, Bonello M, et al. In vivo validation of the adequacy calculator for continuous renal replacement therapies. Crit Care. 2005:9:R266-73.

14. Davenport A, Bouman C, Kirpalani A, et al. Delivery of renal replacement therapy in acute kidney injury: what are the key issues? Clin J Am Soc Nephrol. 2008:3:869-75.

15. Marshall MR. Current status of dosing and quantification of acute renal replacement therapy. Part 1: mechanisms and consequences of therapy under-delivery. Nephrology (Carlton). 2006;11:171-80.

16. Davenport A, Farrington K. Dialysis dose in acute kidney injury and chronic dialysis. Lancet. 2010;375:705-6.

17. Goldstein $\mathrm{SL}$, Currier $\mathrm{H}$, Graf $\mathrm{CD}$, et al. Outcome in children receiving continuous venovenous hemofiltration. Pediatrics. 2001;107:1309-12.

18. Gillespie RS, Seidel K, Symons JM. Effect of fluid overload and dose of replacement fluid on survival in hemofiltration. Pediatr Nephrol. 2004;19:1394-9.

19. Foland JA, Fortenberry JD, Warshaw BL, et al. Fluid overload before continuous hemofiltration and survival in critically ill children: a retrospective analysis. Crit Care Med. 2004;32:1771-6.

20. Payen $D$, de Pont AC, Sakr $Y$, et al. A positive fluid balance is associated with a worse outcome in patients with acute renal failure Crit Care 2008:12.R74.

21. Bouchard J, Soroko SB, Chertow GM, et al. Fluid accumulation, survival and recovery of kidney function in critically ill patients with acute kidney injury. Kidney Int. 2009:76:422-7.

22. Sutherland SM, Zappitelli M, Alexander SR, et al. Fluid overload and mortality in children receiving continuous renal replacement therapy: the prospective pediatric continuous renal replacement therapy registry. Am J Kidney Dis. 2010:55:316-25.

23. Lowrie EG, Laird NM, Parker TF, Sargent JA. Effect of the hemodialysis prescription of patient morbidity: report from the national cooperative dialysis study. N Engl J Med. 1981;305:1176-81.

24. Parker TF $3^{\text {rd }}$, Husni L, Huang W, Lew N, Lowrie EG. Survival of hemodialysis patients in the united states is improved with a greater quantity of dialysis. Am J Kidney Dis. 1994;23:670-80.

25. Hakim RM, Breyer J, Ismail N, Schulman G. Effects of dose of dialysis on morbidity and mortality. Am J Kidney Dis. 1994;23:661-9.

26. Held PJ, Port FK, Wolfe RA, et al. The dose of hemodialysis and patient mortality. Kidney Int. 1996:50:550-6.

27. Joannes-Boyau O, Honoré PM, Perez P, et al. High-volume versus standard-volume haemofiltration for septic shock patients with acute kidney injury (IVOIRE study): a multicentre randomized controlled trial. Intensive Care Med. 2013:39:1535-46. 
28. Park JT, Lee H, Kee YK, et al. High-dose versus conventional-dose continuous venovenous hemodiafiltration and patient and kidney survival and cytokine removal in sepsis-associated acute kidney injury: a randomized controlled trial. Am J Kidney Dis. 2016;68:599-608.

29. Fayad Al, Buamscha DG, Ciapponi A. Intensity of continuous renal replacement therapy for acute kidney injury. Cochrane Database Syst Rev. 2016;10:CD010613.

30. Venkataraman R, Kellum JA, Palevsky P. Dosing patterns for continuous renal replacement therapy at a large academic medical center in the united states. J Crit Care. 2002;17:246-50.

31. Claure-Del Granado R, Macedo E, Chertow GM, et al. Effluent volume in continuous renal replacement therapy overestimates the delivered dose of dialysis. Clin J Am Soc Nephrol. 2011;6:467-75.

32. Paganini EP. Dialysis is not dialysis is not dialysis! Acute dialysis is different and needs help! Am J Kidney Dis. 1998;32:832-3.

33. Kanagasundaram NS, Greene T, Larive AB, et al. Prescribing an equilibrated intermittent hemodialysis dose in intensive care unit acute renal failure. Kidney Int. 2003;64:2298-310.

34. Marshall MR, Golper TA, Shaver MJ, Alam MG, Chatoth DK. Urea kinetics during sustained low-efficiency dialysis in critically ill patients requiring renal replacement therapy. Am J Kidney Dis. 2002;39:556-70.

35. Himmelfarb J, Evanson J, Hakim RM, et al. Urea volume of distribution exceeds total body water in patients with acute renal failure. Kidney Int. 2002;61:317-23.

36. Carson RC, Kiaii M, MacRae JM. Urea clearance in dysfunctional catheters is improved by reversing the line position despite increased access recirculation. Am J Kidney Dis. 2005;45:883-90.

37. Leblanc M, Fedak S, Mokris G, Paganini EP. Blood recirculation in temporary central catheters for acute hemodialysis. Clin Nephrol. 1996:45:315-9.

38. Little MA, Conlon PJ, Walshe JJ. Access recirculation in temporary hemodialysis catheters as measured by the saline dilution technique. Am J Kidney Dis. 2000;36:1135-9.

39. Oliver MJ, Edwards LJ, Treleaven DJ, Lambert K, Margetts PJ. Randomized study of temporary hemodialysis catheters. Int J Artif Organs. 2002;25:40-4.
40. Level C, Lasseur C, Chauveau P, et al. Performance of twin central venous catheters: influence of the inversion of inlet and outlet on recirculation. Blood Purif. 2002;20:182-8.

41. Klouche K, Amigues L, Deleuze S, Beraud JJ, Canaud B. Complications, effects on dialysis dose, and survival of tunneled femoral dialysis catheters in acute renal failure. Am J Kidney Dis. 2007;49:99-108.

42. Uchino S, Fealy N, Baldwin I, Morimatsu H, Bellomo R. Continuous is not continuous: the incidence and impact of circuit "down-time" on uraemic control during continuous veno-venous haemofiltration. Intensive Care Med. 2003;29:575-8.

43. Feldhoff $P$, Turnham $T$, Klein $E$. Effect of plasma proteins on the sieving spectra of hemofilters. Artif Organs. 1984;8:186-92.

44. Macedo E, Claure-Del Granado R, Mehta RL. Effluent volume and dialysis dose in CRRT: time for reappraisal. Nat Rev Nephrol. 2011;8:57-60.

45. Jaffrin MY. Convective mass transfer in hemodialysis. Artif Organs. 1995;19:1162-71.

46. Garred L, Leblanc M, Canaud B. Urea kinetic modeling for CRRT. Am J Kidney Dis. 1997;30 5 Suppl 4:S2-9.

47. Fall P, Szerlip HM. Continuous renal replacement therapy: cause and treatment of electrolyte complications. Semin Dial. 2010;23:581-5.

48. Morimatsu H, Uchino S, Bellomo R, Ronco C. Continuous renal replacement therapy: does technique influence electrolyte and bicarbonate control? Int J Artif Organs. 2003;26:289-96.

49. Lewis SJ, Mueller BA. Antibiotic dosing in critically ill patients receiving CRRT: underdosing is overprevalent. Semin Dial. 2014;27:441-5.

50. Lewis SJ, Mueller BA. Antibiotic dosing in patients with acute kidney injury: "enough but not too much". J Intensive Care Med. 2016;31:164-76.

51. Wooley JA, Btaiche IF, Good KL. Metabolic and nutritional aspects of acute renal failure in critically ill patients requiring continuous renal replacement therapy. Nutr Clin Pract. 2005;20:176-91.

52. Honoré PM, De Waele E, Jacobs R, et al. Nutritional and metabolic alterations during continuous renal replacement therapy. Blood Purif. 2013;35:279-84 